\title{
FEASIBILITY STUDY THE GANGSA UBUD PRIVATE VILLA \& SPA DI DESA PAYOGAN, KECAMATAN UBUD, KABUPATEN GIANYAR
}

\author{
The Suyanto Sindudarmo ${ }^{1}$ \\ Ida Bagus Panji Sedana ${ }^{2}$
}

${ }^{1}$ Fakultas Ekonomi dan Bisnis Universitas Udayana, Bali, Indonesia
e-mail: suyanto.sindudarmo@ gmail.com
${ }^{2}$ Fakultas Ekonomi dan Bisnis Universitas Udayana, Bali, Indonesia

\begin{abstract}
ABSTRAK
Sektor pariwisata merupakan salah satu sumber penerimaan keuangan negara yang penting. Jumlah kedatangan wisatawan mancanegara di Bali semakin meningkat baik kuantitas maupun kualitasnya yang menyebabkan perlunya peningkatan atas fasilitas pariwisata. Salah satunya adalah dengan penyediaan jasa akomodasi wisata (kamar) yang baik sesuai dengan kebutuhan dan harapan tamu, namun untuk menyediakan jasa akomodasi yaitu melalui pendirian sebuah tempat penginapan harus memperhatikan aspek-aspek studi kelayakan. Hasil analisis studi kelayakan ini akan menunjukkan hasil tentang layak atau tidaknya proyek/investasi tersebut dilaksanakan. Penelitian ini dilakukan di kawasan di desa Payogan, Kecamatan Ubud, Kabupaten Gianyar, Bali, yaitu proyek investasi/pembangunan The Gangsa Ubud Private Villa \& Spa. Metode analisis data yang digunakan lebih menitikberatkan pada analisis aspek pasar dan pemasaran, dan analisis aspek keuangan. Hasil penelitian yang didapat menunjukan ide bisnis atas The Gangsa Ubud Private Villa \& Spa layak dilaksanakan berdasarkan aspek pasar dan pemasaran dan aspek keuangan.
\end{abstract}

Kata Kunci: kelayakan, potensi pasar, analisis pasar, analisis pemasaran,analisis keuangan

\begin{abstract}
The tourism sector is one of the important sources of state revenue. The arrival's number of foreign tourist to Bali is increasing both of quantity and quality, therefore the improvement of tourism facilities is needed. One of the example is providing good accommodation (rooms) in accordance with the needs and expectations of guests, but to provide accommodation services through the development of a lodging should give attention to aspects of the feasibility study. The results of this feasibility study will show the project / investment is feasible or not feasible. This research was conducted in Payogan village, Ubud district, Gianyar regency, Bali, which is the investment / construction project of The Gangsa Ubud Private Villa \& Spa located. Data analysis methods used are more focused on the analysis of market and marketing aspects, and analysis of financial aspects. Research result indicates that business idea for gangsa Ubud Private Villa \& Spa is feasible based on market and marketing aspects and financial aspects.
\end{abstract}

Keywords: feasibility, market potential, market analysis, marketing analysis, financial analysis 


\section{PENDAHULUAN}

Direktorat Jenderal Penataan Ruang Kementerian Pekerjaan Umum, menyatakan bahwa Indonesia dikenal sebagai salah satu destinasi pariwisata internasional, bahkan apabila dibandingkan dengan destinasi lain, Indonesia mempunyai pertumbuhan positif peringkat kedua setelah Malaysia. Apabila dibandingkan dengan Australia, Singapura, Thailand dan Vietnam maka Indonesia mempunyai pertumbuhan jumlah kedatangan wisatawan mancanegara lebih tinggi.

Berdasarkan data dari Balai Informasi Penataan Ruang, Direktorat Jenderal Penataan Ruang Kementerian Pekerjaan Umum, dinyatakan bahwa preferensi produk wisatawan mancanegara dalam mengunjungi Indonesia tertinggi adalah liburan $(59,80 \%)$ dan bisnis $(25,11 \%)$. Sisanya memiliki maksud mengunjungi teman, dinas, konvensi, keagamaan, olah raga, pendidikan, kesehatan, dan lainnya.

Bappenas menyatakan bahwa Perekonomian Provinsi Bali sangat ditunjang oleh sektor pariwisata. Struktur PDRB Provinsi Bali menunjukan sektor-sektor yang berorientasi pada pariwisata seperti sektor perdagangan, hotel dan restoran, memberikan kontribusi terbaik terhadap total PDRB Provinsi Bali, disusul oleh sektor pertanian yang selain berperan sebagai sentra produksi, juga berperan sebagai kawasan wisata pertanian. Hal ini menjadikan pariwisata sebagai tulang punggung perekonomian Provinsi Bali.

Potensi objek-objek wisata di Pulau Bali tersebar di daerah pegunungan, danau, dan pantai. Karakteristik fisik dan non-fisik budaya yang unik dan khas 
juga menjadi salah satu daya tarik pariwisata Pulau Bali. Hal ini menjadikan Pulau Bali memiliki paket wisata yang lengkap, mulai dari paket wisata alam pesisir, alam pegunungan, alam danau, religi, perilaku seni dan budaya, seni arsitektur bangunan, kerajinan tangan, makanan, hingga wisata rekreasi modern, belanja, dan MICE (Meeting, Incentive, Conference and Exhibition).

Jumlah kedatangan wisatawan mancanegara di Bali yang besar dan semakin meningkat baik kuantitas maupun kualitasnya, menyebabkan perlunya peningkatan atas fasilitas pariwisata menjadi semakin baik untuk dapat meningkatkan kualitas pelayanan dan kepuasan tamu. Salah satunya adalah dengan penyediaan jasa akomodasi wisata (kamar) yang baik sesuai dengan kebutuhan dan harapan tamu.

Pengertian akomodasi wisata menurut Badan Pusat Statistik (2015) adalah suatu usaha yang menggunakan suatu bangunan atau sebagian bangunan yang disediakan secara khusus, dan setiap orang dapat menginap, makan, serta memperoleh pelayanan dan fasilitas lainnya dengan pembayaran. Salah satu jenis tempat penginapan yang dikembangkan di Bali adalah Villa. Villa adalah salah satu sarana akomodasi lain dari hotel yang menawarkan layanan dan suasana untuk menjalani kehidupan pribadi lebih dari usaha akomodasi lainnya. Biasanya villa dalam bentuk bangunan tunggal atau kompleks bangunan dengan berbagai fasilitas pendukung seperti rumah keluarga, dapur, kamar tidur, ruang tamu, kamar mandi, kolam renang, garasi, dan lain-lain.

Perusahaan penyedia sarana akomodasi wisata dalam bentuk villa yang akan didirikan adalah The Gangsa Ubud Private Villa \& Spa. Pemilihan Villa 
sebagai sarana akomodasi wisata yang akan dibangun dilatarbelakangi oleh alasan-alasan : tren wisatawan yang memilih villa semakin meningkat, jumlah kamar tidak terlalu banyak sehingga kualitas pelayanan kepada tamu bisa maksimal, lebih mudah mengisi tingkat hunian kamar, dan harga jual kamar lebih tinggi dibandingkan dengan hotel biasa. Lokasi dari rencana investasi ini adalah di desa Payogan, Kecamatan Ubud, Kabupaten Gianyar, Bali. Perusahaan ini merupakan pengembangan dari grup usaha Kayumanis yang telah mempunyai usaha sejenis dan telah beroperasi sebanyak 4 unit di Bali, yaitu : Kayumanis Ubud Private Villa \& Spa, Kayumanis Nusa Dua Private Villa \& Spa, Kayumanis Jimbaran Private Estate \& Spa dan The Gangsa Sanur Private Villa \& Spa. Adapun jenis usahanya meliputi jasa penyediaan kamar, restaurant, dan Spa. Areal yang akan dibangun mempunyai luas tanah sebesar $8.000 \mathrm{~m}^{2}$ dan akan didirikan sebanyak 15 unit villa, 1 unit restoran, 1 unit spa, dan fasilitas pendukung lainnya seperti lobby dan kantor. Nilai investasi yang akan dilakukan membutuhkan dana senilai Rp 49.021.583.000,--

Suliyanto (2010) menyatakan studi kelayakan bisnis merupakan penelitian yang bertujuan untuk memutuskan apakah sebuah ide bisnis layak untuk dilaksanakan atau tidak. Sebuah ide bisnis dinyatakan layak untuk dilaksanakan jika ide tersebut dapat mendatangkan manfaat yang lebih besar bagi semua pihak (stake holder) dibandingkan dampak negatif yang ditimbulkan.

Menurut Georgakellos dan Marcis (2009), dikatakan bahwa : "Feasibility studies aim to objectively and rationally uncover the strengths and weaknesses of an existing business or proposed venture, opportunities and threats present in the 
environment, the resources required to carry through, and ultimately the prospects for success".

"Studi kelayakan bertujuan untuk secara objektif dan rasional mengungkap kekuatan dan kelemahan dari bisnis yang sudah ada atau usaha yang diusulkan, peluang dan ancaman yang ada di lingkungan, sumber daya yang diperlukan untuk melaksanakan, dan akhirnya prospek untuk sukses".

Aspek-aspek yang perlu diperhatikan dalam mendirikan usaha The Gangsa Ubud Private Villa \& Spa, yaitu antara lain :

Aspek pasar dan pemasaran. Terdapat beberapa usaha sejenis yang berapa di wilayah yang sama atau berdekatan dengan rencana usaha dari The Gangsa Ubud Private Villa \& Spa, antara lain The Samaya, Komaneka, Kupu-Kupu Barong, dan Como Shambala. Bagaimana perusahaan mampu memenangkan pasar dengan menggunakan strategi pemasaran yang tepat.

Aspek Finansial. Aspek yang menyangkut pendanaan yang diperlukan untuk mendirikan usaha ini, proyeksi pendapatan serta biaya-biaya yang akan dikeluarkan. Keputusan investasi dapat dikatakan layak untuk dilaksanakan bilamana dapat memberikan keuntungan secara keuangan maupun non keuangan. Secara keuangan dikatakan layak bilamana ada hasil lebih dari selisih besarnya hasil yang diperoleh dari investasi dengan biaya yang dikeluarkan untuk investasi.

Menurut Kasmir dan Jakfar (2012), feasibility study didefinisikan sebagai suatu kegiatan yang mempelajari secara mendalam tentang suatu usaha atau bisnis yang akan dijalankan, dalam rangka menentukan layak atau tidak usaha tersebut 
dijalankan. Pengertian tersebut mengandung dua hal penting, yaitu penelitian yang mendalam dan kelayakan.

Menurut Kasmir dan Jakfar (2012), feasibility study didefinisikan sebagai suatu kegiatan yang mempelajari secara mendalam tentang suatu usaha atau bisnis yang akan dijalankan, dalam rangka menentukan layak atau tidak usaha tersebut dijalankan. Pengertian tersebut mengandung dua hal penting, yaitu penelitian yang mendalam dan kelayakan.

Mempelajari secara mendalam artinya meneliti secara sungguh-sungguh data dan informasi yang ada, kemudian diukur, dihitung, dan dianalisis hasil penelitian tersebut dengan menggunakan metode-metode tertentu. Penelitian yang dilakukan terhadap usaha yang akan dijalankan dengan ukuran tertentu, sehingga diperoleh hasil maksimal dari penelitian tersebut.

Kelayakan artinya penelitian yang dilakukan secara mendalam tersebut dilakukan untuk menentukan apakah usaha yang akan dijalankan akan memberikan manfaat yang lebih dibandingkan dengan biaya yang dikeluarkan.

Husnan dan Muhamad (2014) menyatakan bahwa feasibility study atau studi kelayakan dilakukan mempunyai tujuan untuk menghindarkan keterlanjuran penanaman modal yang terlalu besar untuk kegiatan yang ternyata tidak menguntungkan. Tentu saja studi kelayakan ini akan memakan biaya, tetapi biaya tersebut relatif kecil apabila dibandingkan dengan risiko kegagalan suatu proyek yang menyangkut investasi dalam jumlah besar. 
William (2005) menyatakan bahwa investasi adalah mengorbankan dollar sekarang untuk dollar di masa yang akan datang. Pengertian ini mengandung dua atribut penting di dalam investasi, yaitu adanya risiko dan tenggang waktu.

Mengorbankan uang artinya menanamkan sejumlah dana dalam suatu usaha saat sekarang atau saat investasi dimulai kemudian mengharapkan pengembalian investasi dengan disertai tingkat keuntungan yang diharapkan di masa yang akan datang dalam waktu tertentu. Pengorbanan dalam bentuk dana yang dilakukan mengandung kepastian, sedangkan hasil yang diharapkan di masa mendatang bersifat tidak pasti, tergantung kondisi di masa akan datang.

Masalah investasi berkaitan erat dengan capital budgeting, yaitu proses evaluasi investasi potensial perusahaan dan memutuskan mana yang akan diterima. Menurut Brigham dan Daves (2008), jika perusahaan berinvestasi terlalu banyak, itu akan menyia-nyiakan modal investor dengan kelebihan kapasitas. Di sisi lain, jika tidak cukup berinvestasi. Peralatan dan perangkat lunak komputernya mungkin tidak cukup modern supaya bisa berproduksi secara kompetitif. Selain itu, jika kapasitasnya tidak memadai, mungkin akan kehilangan pangsa pasar untuk menyaingi perusahaan lain, dan untuk mendapatkan kembali pelanggan yang hilang memerlukan biaya penjualan yang besar, pengurangan harga, atau peningkatan produk, yang semuanya mahal harganya. Sedangkan Jones (2004) menyatakan bahwa keputusan investasi adalah suatu kebijakan atau keputusan yang diambil untuk menanamkan modal pada satu atau lebih aset untuk mendapatkan keuntungan dimasa yang akan datang dengan mengorbankan kekayaan saat ini. 
Husnan (2008), untuk melakukan studi kelayakan, terlebih dahulu harus ditentukan aspek-aspek apa saja yang akan dipelajari, walaupun belum ada kesepakatan tentang aspek apa saja yang perlu diteliti, tetapi pada umumnya penelitian akan dilakukan terhadap aspek-aspek pasar, aspek dan teknis keuangan, aspek hukum dan aspek ekonomi sosial negara. Tergantung pada besar kecilnya dana yang tertanan dalam investasi tersebut, maka terkadang juga ditambah studi tentang dampak sosial.

Pasar dan pemasaran merupakan dua sisi yang tidak dapat dipisahkan satu sama lainnya. Pasar dan pemasaran memiliki tingkat ketergantungan yang tinggi dan saling memengaruhi satu sama lainnya. Bisa diartikan bahwa, setiap ada kegiatan pasar selalu diikuti oleh pemasaran dan setiap kegiatan pemasaran adalah untuk mencari atau menciptakan suatu pasar.

Kasmir dan Jakfar (2012), pengertian pasar secara sederhana dapat diartikan sebagai tempat bertemunya para penjual dan pembeli untuk melakukan transaksi. Pengertian ini mengandung arti pasar memiliki tempat atau lokasi tertentu sehingga memungkinkan pembeli atau penjual bertemu untuk melakukan transaksi jual beli produk baik barang maupun jasa.

Pengertian lain yang lebih luas tentang pasar adalah himpunan pembeli nyata dan pembeli potensial atas suatu produk. Berdasarkan pengertian ini mengandung arti bahwa pasar merupakan kumpulan atau himpunan dari para pembeli, baik pembeli nyata maupun pembeli potensial atas suatu produk atau jasa tertentu. Pasar nyata maksudnya adalah himpunan konsumen yang memiliki minat, pendapatan, dan akses pada suatu produk atau jasa tertentu. Di dalam pasar 
nyata biasanya konsumen pasti melakukan transaksi, hal ini disebabkan konsumen didukung dengan minat atau keinginan untuk membeli serta memiliki pendapatan atau akses. Jika masih merupakan keinginan dan suatu saat apabila telah memiliki pendapatan dan ada akses mereka akan membeli, kelompok ini merupakan pasar potensial.

Umar (2002) Pasar juga dapat diartikan pula sebagai suatu mekanisme yang terjadi antara pembeli dan penjual atau tempat pertemuan antara kekuatan permintaan dan penawaran untuk membentuk suatu harga. Kasmir dan Jakfar (2012), yang dimaksud dengan permintaan adalah jumlah barang dan jasa yang diminta konsumen pada berbagai tingkat harga pada suatu waktu tertentu.

Agar investasi atau bisnis yang akan dijalankan dapat berhasil dengan baik, maka sebelumnya perlu dilakukan strategi bersaing yang tepat. Unsur strategi persaingan ini adalah menentukan segmentasi pasar (segmentation), menetapkan pasar sasaran (targeting), dan menentukan posisi pasar (positioning), atau sering disebut dengan STP.

Segmentasi pasar artinya membagi pasar menjadi beberapa kelompok pembeli yang berbeda yang mungkin memerlukan produk atau marketing mix yang berbeda pula. Segmentasi pasar perlu dilakukan mengingat di dalam suatu pasar terdapat banyak pembeli yang berbeda keinginan dan kebutuhannya, dimana setiap perbedaan memiliki potensi untuk menjadi pasar sendiri. Melakukan segmentasi pasar terdiri dari beberapa variabel yang harus diperhatikan. Tujuannya adalah agar segmentasi yang telah dilakukan tepat sasaran. Salah 
dalam menentukan variabel segmen akan berdampak gagalnya sasaran yang ingin dicapai.

Melakukan segmentasi pasar terdiri dari beberapa variabel yang harus diperhatikan. Tujuannya adalah agar segmentasi yang telah dilakukan tepat sasaran. Salah dalam menentukan variabel segmen akan berdampak gagalnya sasaran yang ingin dicapai. Variabel untuk melakukan segmentasi terdiri dari segmentasi pasar konsumen dan segmentasi pasar industrial.

Analisis keuangan menurut Sofyan (2003) adalah kegiatan melakukan penilaian dan penentuan satuan rupiah terhadap aspek-aspek yang dianggap layak dari keputusan yang dibuat dalam tahapan analisis usaha. Menurut Umar (2002) tujuan menganalisis aspek keuangan dari suatu studi kelayakan adalah untuk menentukan rencana investasi melalui perhitungan biaya dan manfaat yang diharapkan, dengan membandingkan antara pengeluaran dan pendapatan seperti ketersediaan dana, biaya modal, kemampuan proyek untuk membayar kembali dana tersebut dalam waktu yang telah ditentukan dan menilai apakah proyek akan berkembang terus.

Menurut Husnan dan Muhammad (2014), sumber-sumber dana yang utama adalah modal sendiri, saham biasa atau saham preferen, obligasi, kredit bank, leasing (sewa guna), project finance. Menurut Sutojo (2002), pembangunan dan pengoperasian proyek dapat dibiayai dengan dua sumber pembiayaan utama antara lain dana sendiri (equity investment) dan pinjaman dari pihak ketiga (project financing). Disamping kedua sumber pembiayaan utama itu, dalam kasus-kasus tertentu diadakan sumber pembiayaan ketiga yang bersifat semi 
modal sendiri, yaitu pinjaman dari pemegang saham (shareholders loan). Dari beberapa pengertian diatas, sumber dana investasi berasal dari modal sendiri dan atau modal pinjaman yang disesuaikan dengan kondisi dan situasi dari masingmasing perusahaan.

Kemampuan proyek memasarkan produk dan menghasilkan keuntungan dipengaruhi oleh berbagai faktor baik internal maupun eksternal perusahaan. Contoh faktor internal adalah biaya pokok-produk yang akan dihasilkan, sedangkan contoh faktor eksternal adalah perkembangan harga produk sejenis di pasar. Apabila diketahui ada faktor-faktor internal atau eksternal yang besar sekali pengaruhnya terhadap kemampuan proyek dalam menghasilkan penjualan dan keuntungan, perlu dikaji tingkat kepekaan (sensitivity analysis) proyek terhadap perubahan faktor-faktor tertentu itu. Contohnya adalah apabila harga jual produk mempunyai pengaruh besar terhadap kemampuan proyek bersaing di pasar, perlu dikaji pengaruh perubahan harga terhadap hasil penjualan, BEP (Break Event Point), pendapatan, laba serta kemampuan proyek dalam memenuhi kewajiban keuangan kepada pihak ketiga.

Sutojo (2006) menyatakan bahwa guna memperoleh jumlah perkiraan permintaan yang lebih dapat dipercaya, diperlukan analisis kepekaan (sensitivity analysis) permintaan, terhadap perubahan faktor tertentu yang dapat mempengaruhi jumlah atau pola permintaan produk. Dengan metode analisis kepekaan, disamping jumlah perkiraan permintaan pertama, akan disusun pula perkiraan permintaan kedua, ketiga dan seterusnya sesuai dengan keperluan yang memasukkan pengaruh perubahan faktor tertentu. 
Umar (2002) menyatakan bahwa pada saat menganalisis perkiraan arus kas dimasa datang, kita berhadapan dengan ketidakpastian, sehingga harus diidentifikasi semua variabel yang mempengaruhinya dan selanjutnya dilakukan analisis kepekaan yang memberikan taksiran optimis dan pesimistik.

Aspek hukum akan membahas masalah kelengkapan dan keabsahan dokumen perusahaan, mulai dari bentuk badan usaha sampai dengan izin-izin yang dimiliki. Kelengkapan dan keabsahan dokumen sangat penting, karena hal ini merupakan dasar hukum yang harus dipegang apabila dikemudian hari timbul masalah. Keabsahan dan kesempurnaan dokumen dapat diperoleh dari pihakpihak yang menerbitkan atau mengeluarkan dokumen tersebut.

Penelitian dalam aspek ekonomi adalah untuk melihat seberapa besar pengaruh yang ditimbulkan jika proyek ini dijalankan. Pengaruh ini terutama terhadap ekonomi secara luas serta dampak sosialnya terhadap masyarakat secara keseluruhan.

Aspek dampak lingkungan merupakan analisis yang paling dibutuhkan pada saat ini, karena setiap proyek yang dijalankan akan sangat besar dampaknya terhadap lingkungan di sekitarnya, baik terhadap darat, air, dan udara, yang pada akhirnya akan berdampak terhadap kehidupan manusia dan lingkungan sekitarnya.

Ismayanti (2010), penyediaan akomodasi wisata adalah usaha yang menyediakan pelayanan penginapan yang dilengkapi dengan pelayanan pariwisata lain, usaha penyediaan akomodasi dapat berupa hotel, villa, pondok wisata, bumi perkemahan, dan akomodasi lain yang digunakan untuk tujuan pariwisata. 
The Gangsa Ubud Private Villa \& Spa merupakan jasa akomodasi wisata yang akan didirikan di Ubud, Gianyar, Bali sehingga perlu dilakukan penilaian dari berbagai aspek yaitu penelitian akan dilakukan terhadap aspek-aspek pasar, keuangan, manajemen, teknis, ekonomi dan sosial serta hukum. Berdasarkan berbagai aspek pada studi kelayakan ini maka kajian yang dilakukan penulis lebih menekankan penelitian pada aspek pasar dan pemasaran dan aspek keuangan.

Aspek pasar yang akan dianalisis meliputi market demand analysis, marketshare, competitor analysis, dan marketing strategy. Aspek keuangan yang dianalisis meliputi proyeksi pendapatan, proyeksi aliran arus kas, dan penilaian investasi. Dari data yang didapatkan dengan instrumen dan pengumpulan data terkait maka pengolahan, penilaian dan analisis akan dilakukan dengan menggunakan beberapa metode penilaian dari aspek pasar dan dari aspek keuangan yang terkait dengan teknik analisis yang peneliti gunakan.

\section{METODE PENELITIAN}

Data kualitatif dalam penelitian meliputi profil The Gangsa Ubud Private Villa \& Spa. Data kuantitaif dalam penelitian ini meliputi : jumlah wisatawan yang datang, lama tamu menginap, tingkat hunian kamar, arus kas, proyeksi tingkat hunian dan total investasi.

Data primer yang digunakan meliputi wawancara dengan pihak terkait, baik mengenai rencana pengelolaan The Gangsa Private Villa \& Spa, perkiraan biaya yang akan dikeluarkan, data teknis bangunan, prediksi penjualan dan organisasi pengelolaan The Gangsa Private Villa \& Spa. Data sekunder merupakan data yang didapat dari pihak-pihak lain yang langsung digunakan 
untuk mendukung penelitian ini antara lain data yang diperoleh dari Badan Pusat Statistik Bali dan Dinas Pariwisata Bali.

Penelitian dilakukan di The Gangsa Private Villa \& Spa dengan cara melakukan wawancara, observasi dan pengolahan data penjualan perusahaan. Tabel 1 merupakan kriteria optimasi yang digunakan dalam penelitian ini.

Tabel 1.

Kriteria Optimasi Feasibility Study

\begin{tabular}{lc}
\hline \multicolumn{1}{c}{ Aspek Feasibility Study } & \multicolumn{1}{c}{ Kriteria } \\
\hline Aspek Pasar dan Pemasaran & Kriteria yang digunakan dalam aspek ini \\
adalah: & $-\quad$ Jumlah wisatawan \\
& $-\quad$ Persaingan \\
Aspek Keuangan & $-\quad$ Strategi Pemasaran \\
& $-\quad$ Market share \\
& Kriteria yang digunakan dalam aspek ini \\
adalah: & $-\quad$ Initial invesment \\
& $-\quad$ Pendapatan dan biaya penjualan \\
& $-\quad$ Operational cash flow \\
& $-\quad$ Perhitungan WACC \\
& $-\quad$ Perhitungan NPV, IRR dan payback \\
Asumsi-asumsi & period \\
& Asumsi-asumsi ini digunakan untuk \\
Sumber: Data diolah 2017 & membatasasi permasalahan dalam penelitian ini \\
\hline
\end{tabular}

Sumber: Data diolah, 2017

\section{HASIL DAN PEMBAHASAN}

Aspek yang akan dikaji adalah aspek pasar dan pemasaran, aspek keuangan. Untuk aspek hukum, manajemen teknis, sosial ekonomi hanya akan di berikan penjelasannya saja, tidak masuk dalam kajian kelayakan.

Setelah data diperoleh dan kemudian dianalisis berdasarkan pada kriteria optimasi feasibility study, maka didapat hasil sebagai berikut: 
Tabel 2.

Hasil Analisis Kriteria Optimasi

\begin{tabular}{|c|c|}
\hline Aspek Feasibility Study & Hasil \\
\hline Aspek pasar dan pemasaran & $\begin{array}{l}\text { Analisa yang dilakukan di dalam aspek pasar } \\
\text { dan pemasaran The Gangsa Private Villa \& Spa } \\
\text { menunjukkan bahwa diasumsikan jumlah } \\
\text { pengunjung yang akan ditarik ke Ubud adalah } \\
\text { sebesar } 10 \% \text { per tahun. Maka menurut aspek ini } \\
\text { pengembangan bisnis layak untuk dilakukan } \\
\text { The Gangsa Private Villa \& Spa. }\end{array}$ \\
\hline Aspek Hukum & $\begin{array}{l}\text { Semua ketentuan hukum yang harus } \\
\text { dilaksanakan The Gangsa Private Villa \& Spa } \\
\text { telah dilakukan, seluruh persyaratan dan } \\
\text { berkas-berkas perusahaan telah lengkap. Maka } \\
\text { pembangunan bisnis layak untuk dilakukan. }\end{array}$ \\
\hline Aspek Manajemen Teknis & $\begin{array}{l}\text { Analisa yang dilakukan pada aspek ini } \\
\text { menghasilkan penjabaran bagaimana proses } \\
\text { kerja di dalam perusahaan, bagaimana proses } \\
\text { pemilihan dan perencanaan produk/jasa yang } \\
\text { ditawarkan, lokasi bisnis, layout, pengawasan } \\
\text { kualitas. Maka menurut aspek ini pembangunan } \\
\text { bisnis layak untuk dilanjutkan. }\end{array}$ \\
\hline Aspek SDM & $\begin{array}{l}\text { Analisis yang dilakukan dalam aspek ini } \\
\text { berdasarkan pertimbangan struktur organisasi, } \\
\text { formasi dan jumlah SDM sudah memadai. } \\
\text { Maka menurut aspek ini pembangunan bisnis } \\
\text { layak untuk dilakukan. }\end{array}$ \\
\hline Aspek Keuangan & $\begin{array}{l}\text { Ada beberapa skenario yamg digunakan dalam } \\
\text { perhitungan aspek keuangan yang menunjukkan } \\
\text { bahwa pembangunan bisnis yang akan } \\
\text { dilakukan adalah layak. }\end{array}$ \\
\hline
\end{tabular}

Sumber: Data diolah, 2017

Pada Tabel 3. terdapat asumsi yang dipergunakan untuk menghitung

WACC:

Tingkat suku bunga pinjaman yang dipergunakan adalah 11,00\%. Tingkat suku bunga ekuitas yang dihitung dengan mempertimbangkan faktor-faktor berikut ini:1) Risk Free rate diasumsikan sebesar yield (SUN) 10 tahun per tanggal 14 November 2017 sebesar 7,26\% (www.djppr.kemenkeu.go.id) yang disesuaikan dengan default spread Indonesia (Baa3) sebesar 2,54\% (Damodaran online per Januari 2017), sehingga diperoleh nilai risk free rate efektif sebesar 
The Suyanto Sindudarmo dan Ida Bagus Panji Sedana. Feasibility Study The Gangsa Ubud...

$4,72 \% .2)$ Levered beta yang digunakan adalah Levered beta dari rata-rata industri perhotelan di Asia sebesar 0,64. 3) Equity Risk Premium (ERP) Indonesia diperoleh dari Damodaran Online per Januari 2017 sebesar 8,82\%.

Tabel 3.

Perhitungan WACC

The Gangsa Ubud Private Villa \& Spa

\begin{tabular}{|c|c|c|}
\hline \multicolumn{3}{|c|}{ Perhitungan WACC } \\
\hline 1 & Komposisi Modal & \\
\hline & Debt-to-Total Asset & $30,60 \%$ \\
\hline & Equity-to-Total Asset & $69,40 \%$ \\
\hline 2 & Cost of Debt & \\
\hline & Cost of Debt & $11,00 \%$ \\
\hline & Tax Rate & $25 \%$ \\
\hline & After Tax-Cost of debt & $8,25 \%$ \\
\hline 3 & Cost of Equity & \\
\hline & Risk-free-rate & $4,72 \%$ \\
\hline & Market Risk Premium & $8,82 \%$ \\
\hline & Levered Beta & 0,64 \\
\hline & Cost of Equity & $8,67 \%$ \\
\hline 4 & Specific Risk & $2,00 \%$ \\
\hline 5 & WACC & $10,54 \%$ \\
\hline
\end{tabular}

Berdasarkan asumsi tersebut di atas, perthitungan WACC sebagaimana terlihat di Tabel 3. menunjukkan nilai WACC yang diperoleh setelah mempertimbangkan tingkat suku bunga pinjaman, ekuitas, dan specific risk adalah adalah $10,54 \%$.

Payback period adalah periode yang diperlukan untuk dapat menutup kembali pengeluaran investasi yang menggunakan aliran kas bersih/proceed. 
Waktu yang diperlukan agar dana yang ditanam pada suatu investasi dapat diperoleh kembali seluruhnya. Payback period dihitung pada Tabel 4.

Tabel 4.

Perhitungan Payback Period

The Gangsa Ubud Private Villa \& Spa

\begin{tabular}{|c|c|}
\hline Keterangan & Jumlah (Rp) \\
\hline Nilai Investasi awal & 49.021 .583 \\
\hline \multirow[t]{2}{*}{ Proceeds tahun ke-1 } & 4.853 .932 \\
\hline & 44.167 .650 \\
\hline \multirow[t]{2}{*}{ Proceeds tahun ke- 2} & 5.990 .194 \\
\hline & 38.177 .456 \\
\hline \multirow[t]{2}{*}{ Proceeds tahun ke-3 } & 7.232 .093 \\
\hline & 30.945 .363 \\
\hline \multirow[t]{2}{*}{ Proceeds tahun ke-4 } & 11.011 .141 \\
\hline & 19.934 .222 \\
\hline Proceeds tahun ke- 5 & 10.224 .132 \\
\hline Sisa & 9.710 .090 \\
\hline
\end{tabular}

Sumber: Data diolah, 2017

Berdasarkan Tabel 4. Dapat diyunjukkan bahwa sisa Investasi setelah proceed ke-5 sebesar Rp 9.710.090,-, sedangkan perkiraan proceed di tahun ke-6 sebesar Rp 12.902.811,-- sehingga waktu yang diperlukan untuk menutupi sisa investasi tersebut adalah selama 0,75 tahun ( $\mathrm{Rp} 9.710 .090,-/ 12.902 .811,-) \times 1$ tahun). Dengan demikian Payback period atas investasi villa adalah $=5,75$ tahun artinya investasi yang ditanamkan tersebut akan kembali dalam waktu 5,75 tahun, lebih cepat dari pada rencana proyeksi 10 tahun (umur ekonomis). Berdasarkan penggunaan metode payback period dalam melakukan penilaian atas investasi villa, maka dapat dikatakan bahwa investasi pembangunan villa adalah feasible.

Net present value (NPV) adalah selisih dari total nilai sekarang atas proceeds yang diterima di masa yang akan datang (total present value of proceeds) dengan nilai tambahan investasi. Perhitungan nilai sekarang memerlukan data proyeksi investasi, proceeds, dan tingkat diskonto. Tingkat diskonto ditentukan sebesar $10,54 \%$. Nilai ini sama dengan WACC. Tambahan 
investasi diestimasi sebesar $\mathrm{Rp}$ 49.021.583.000,-. Hasil perhitungan diperoleh NPV sebesar Rp 11.707.906.000,-. Perhitungan NPV disajikan pada Tabel 5. berikut ini:

Tabel 5.

Perhitungan Net Present Value

The Gangsa Ubud Private Villa \& Spa

\begin{tabular}{rccc}
\hline Tahun & $\begin{array}{c}\text { Proceeds } \\
(\boldsymbol{R} \boldsymbol{p})\end{array}$ & $\begin{array}{c}\boldsymbol{D F} \\
(\mathbf{1 0 , 5 4 \% )}\end{array}$ & $\begin{array}{c}\boldsymbol{P V} \boldsymbol{o f} \text { Proceeds } \\
(\boldsymbol{R} \boldsymbol{p})\end{array}$ \\
\hline 1 & 4.853 .932 & 0,9047 & 4.391 .172 \\
2 & 5.990 .194 & 0,8184 & 4.902 .463 \\
3 & 7.232 .093 & 0,7404 & 5.354 .564 \\
4 & 11.011 .141 & 0,6698 & 7.375 .290 \\
5 & 10.224 .132 & 0,6059 & 6.195 .266 \\
6 & 11.823 .737 & 0,5482 & 6.481 .492 \\
7 & 12.902 .811 & 0,4959 & 6.398 .693 \\
8 & 14.818 .614 & 0,4486 & 6.648 .156 \\
9 & 16.269 .567 & 0,4059 & 6.603 .229 \\
10 & 17.373 .878 & 0,3672 & 6.379 .164 \\
\multicolumn{7}{c}{ Total Present value of proceed } & & 60.729 .488 \\
& Investasi Awal & & 49.021 .583 \\
\multicolumn{2}{c}{ NPV } & & 11.707 .906 \\
\hline
\end{tabular}

Sumber: Data diolah, 2017

Nilai NPV yang diperoleh adalah positif sebesar Rp 11.707.906.000,-. Berdasarkan metode Net Present Value dapat dikatakan bahwa investasi vila adalah feasible.

IRR mengandung makna suku bunga yang dapat diberikan investasi yang akan memberikan NPV sama dengan nol. Syarat kelayakannya adalah IRR lebih besar dari tingkat suku bunga yang digunakan sebagai acuan. Hasil perhitungan IRR disajikan pada Tabel 6. sebagai berikut: 
Tabel 6.

Perhitungan IRR The Gangsa Ubud Private Villa \& Spa

\begin{tabular}{cccccc}
\hline & Proceeds & $\mathbf{1 0 , 5 4 \%}$ & PV & $\mathbf{1 5 , 0 0 \%}$ & PV \\
\hline 1 & 4.853 .932 & 0,9047 & 4.391 .172 & 0,8696 & 4.220 .811 \\
2 & 5.990 .194 & 0,8184 & 4.902 .463 & 0,7561 & 4.529 .448 \\
3 & 7.232 .093 & 0,7404 & 5.354 .564 & 0,6575 & 4.755 .218 \\
4 & 11.011 .141 & 0,6698 & 7.375 .290 & 0,5718 & 6.295 .655 \\
5 & 10.224 .132 & 0,6059 & 6.195 .266 & 0,4972 & 5.083 .201 \\
6 & 11.823 .737 & 0,5482 & 6.481 .492 & 0,4323 & 5.111 .728 \\
7 & 12.902 .811 & 0,4959 & 6.398 .693 & 0,3759 & 4.850 .645 \\
8 & 14.818 .614 & 0,4486 & 6.648 .156 & 0,3269 & 4.844 .231 \\
9 & 16.269 .567 & 0,4059 & 6.603 .229 & 0,2843 & 4.624 .826 \\
10 & 17.373 .878 & 0,3672 & 6.379 .164 & 0,2472 & 4.294 .557 \\
& & & 60.729 .488 & & 48.610 .320 \\
& & 49.021 .583 & & 49.021 .583 \\
& & & 11.707 .906 & & $(411.262)$ \\
\hline
\end{tabular}

Sumber: Lampiran 9 (Data diolah)

$$
\begin{aligned}
& \mathrm{IRR}=\mathrm{DF}_{\mathrm{p}}+\frac{\mathrm{NPV}_{\mathrm{p}}}{\left(\mathrm{PV}_{\mathrm{p}}-\mathrm{PV}_{\mathrm{N}}\right.} \times\left(\mathrm{DF}_{\mathrm{N}}-\mathrm{DF}_{\mathrm{P}}\right) \\
& \mathrm{IRR}=10,54 \%+\frac{11.707 .906}{(60.729 .488-48.610 .320} \times(15 \%-10,54 \%) \\
& \mathrm{IRR}=14,85 \%
\end{aligned}
$$

Hasil analisis diperoleh IRR sebesar 14,85\%. Nilai IRR ini lebih besar daripada tingkat diskonto sebesar 10,54\%, sehingga investasi pembangunan villa adalah feasible.

PI menghitung perbandingan antara nilai arus kas bersih yang akan datang dengan nilai investasi yang sekarang (total present value of proceed/tambahan investasi). Profitability Index harus lebih besar dari 1, agar investasi layak dilaksanakan. Semakin besar PI, investasi semakin layak. PI dihitung dengan rumus sebagai berikut: 


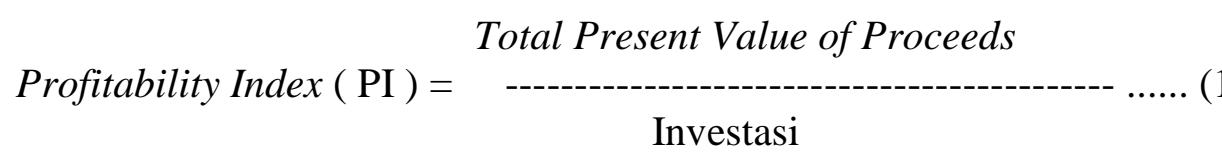

Keterangan:

Jika PI >1 ; makainvestasi tersebut dapat dijalankan (feasible)

Jika PI $<1$; investasi tersebut tidak layak dijalankan (unfeasible)

Profitability Index $(\mathrm{PI})=\quad \begin{gathered}\mathrm{Rp} \text { 60.729.488,- } \\ -\mathrm{-Pp} 49.021 .583,-\end{gathered}$

Hasil analisis PI diperoleh nilai sebesar 1,24. Nilai PI sebesar 1,24 lebih besar daripada 1, sehingga investasi villa adalah feasible.

AVR menggambarkan rata-rata tingkat keuntungan yang diperoleh dari investasi. Hasil perhitungan AVR adalah 12,54\%. Bila dibandingkan dengan tingkat WACC yang berlaku (10,54\%), maka AVR sebesar 12,54\% masih lebih besar, sehingga investasi pembangunan villa adalah feasible. Berdasarkan analisis aspek keuangan, seperti pay back period, NPV, IRR, PI, dan AVR investasi The Gangsa Ubud Private Villa \& Spa layak dilaksanakan.

Keputusan investasi untuk investor The Gangsa Ubud Private Villa \& Spa diambil berdasarkan peritungan empat metode yaitu payback period, NPV, IRR, dan PI. Bila berdasarkan hasil perhitungan diperoleh angka yang layak maka investasi dapat dilaksanakan. Skenario ini dibuat untuk melihat proyeksi keuangan investor dalam tiga kondisi yang berbeda sehingga bila salah satu kondisi ini terjadi investor dapat mempertimbangkan apakah investasi ini masih layak atau tidak. Tujuan dari analisis skenario ini adalah untuk melihat perubahan nilai payback period, NPV, IRR, dan PI. bila beberapa faktor yang dalam beberapa 
waktu bersamaan berubah. Faktor-faktor yang mengalami perubahan dalam analisis skenario ini : 1) Harga sewa diturunkan sebesar 5 USD, cost of debt dinaikkan $1 \%$ dan biaya operasional mengalami kenaikan, kecuali biaya penyusutan. 2) Harga sewa diturunkan sebesar 10 USD, cost of debt dinaikkan 2\% dan biaya operasional mengalami kenaikan, kecuali biaya penyusutan.

Hasil analisis sensitivitas ditunjukkan pada Tabel 7.

Tabel 7.

Analisis Sensitivitas

\begin{tabular}{lccc}
\hline Variabel & Skenario Optimis & Skenario Moderat & Skenario Pesimis \\
\hline DF (WACC) & $10,54 \%$ & $10,77 \%$ & $11 \%$ \\
Harga Sewa Rata-rata & Rp 4.557 .000 & Rp 4.449 .000 & Rp 4.375 .000 \\
Total Biaya Operasi & Rp 9.220 .787 .000 & Rp 9.303 .366 .000 & Rp 9.367 .087 .000 \\
NPV & Rp 11.707 .906 .000 & Rp 7.244 .872 .000 & Rp 1.121 .609 .000 \\
IRR & $14,85 \%$ & $13,55 \%$ & $11,47 \%$ \\
Payback Period & 5,75 tahun & 5,97 tahun & 6,25 tahun \\
Profitability Index & 1,24 & 1,15 & 1,02 \\
\hline
\end{tabular}

Sumber: Data diolah, 2017

Tabel 8.

Keputusan Investasi

\begin{tabular}{llll}
\hline Metode & Skenario & Hasil Perhitungan & Keputusan Investasi \\
\hline NPV & OPTIMIS & Rp 11.707.906.000 & Layak \\
& MODERAT & Rp 7.244.872.000 & Layak \\
& PESIMIS & Rp 1.121 .609 .000 & Layak \\
IRR & OPTIMIS & $14,85 \%$ & Layak \\
& MODERAT & $13,55 \%$ & Layak \\
Payback Period & PESIMIS & $11,47 \%$ & Layak \\
& OPTIMIS & 5,75 tahun & Layak \\
& MODERAT & 5,97 tahun & Layak \\
Profitability Index & PESIMIS & 6,25 tahun & Layak \\
& OPTIMIS & 1,24 & Layak \\
& MODERAT & 1,15 & Layak \\
& PESIMIS & 1,02 & Layak \\
\hline
\end{tabular}

Sumber: Data diolah, 2017

Berdasarkan dari skenario diatas, kesimpulan dari hasil keputusan investasi yang akan diambil adalah sebagai berikut:

Pada saat kondisi MODERAT menghasilkan NPV positif sebesar Rp 7.244.872.000 (layak) dengan IRR sebesar 13,55\% lebih besar dari biaya modal 10,77\% (layak). Payback period 5,97 tahun lebih cepat dari rencana proyek 10 
tahun (layak) sedangkan PI 1,15 (layak). Secara keseluruhan investasi dikatakan layak karena tingkat pengembaliannya lebih besar dari biaya modal rata-rata tertimbang.

Pada saat kondisi PESIMIS menghasilkan NPV positif sebesar Rp 1.121.609.000(layak) dengan IRR sebesar 11,47\% lebih besar dari biaya modal $11 \%$ (layak). Payback period 6,25 tahun lebih cepat dari rencana proyek 10 tahun (layak) sedangkan PI 1,02 (layak). Secara keseluruhan investasi dikatakan layak karena tingkat pengembaliannya lebih besar dari biaya modal rata-rata tertimbang.

\section{SIMPULAN DAN SARAN}

Berdasarkan hasil analis dan pembahasan dalam bab sebelumnya maka penelitian yang bertujuan untuk kelayakan pendirian The Gangsa Ubud Private Villa \& Spa di Payogan, Kecamatan Ubud, Kabupaten Gianyar menghasilkan kesimpulan bahwa Aspek pasar dan pemasaran adalah melakukan analisa pada permintaan pasar dengan menggunakan trend linear. Berdasarkan perhitungan didapatkan data-data yaitu jumlah tamu yang menginap pada tahun 2018 adalah sekitar 10.066.888 orang. Angka pertumbuhan rata-rata lamu tamu menginap adalah 2,796 hari. Angka pertumbuhan tingkat hunian kamar mencapai 61,83\%. Angka pertumbuhan wisatawan yang menginap menurut jenis hotel berbintang adalah sebesar 14,13\%. Jumlah kamar yang tersedia di Bali pada tahun 2016 adalah sebesar 31.596 kamar, sedangkan pada tahun 2018 jumlah kamar diperkirakan menjadi 32.231 kamar. Jumlah kebutuhan kamar pada tahun 2018 
berdasarkan proyeksi jumlah kedatangan tamu diperkirakan sebesar 73.365 kamar sehingga jumlah kamar yang masih potensial untuk dipenuhi di Bali adalah sebesar 41.134 kamar. Kebutuhan di Ubud berdasarkan asumsi sebesar 10\% dari total kamar di Bali, maka potensi penambahan kamar di Ubud untuk tahun 2018 adalah sebesar 4.113 kamar.

Strategi pemasaran untuk The Gangsa Ubud Private Villa \& Spa berdasarkan analisis matrik Internal-Eksternal adalah strategi pertumbuhan (penetrasi pasar dan pengembangan pasar). Alternatif strategi yang diterapkan agar The Gangsa Ubud Private Villa \& Spa dapat melakukan penetrasi pasar dan juga mengembangkan pasar adalah pemasaran yang gencar seperti sering mengikuti acara pameran/trade show yang diadakan pemerintah pada acara pariwisata di luar negeri, selain itu memberikan potongan harga kepada travel agent yang bekerja sama agar merujuk konsumen mereka menginap di The Gangsa Ubud Private Villa \& Spa.

Pemberian diskon dilakukan pada awal-awal The Gangsa Ubud Private Villa \& Spa ini dijalankan, hal tersebut dilakukan agar The Gangsa Ubud Private Villa \& Spa mendapat pengalaman dalam melayani konsumen dan juga mendapat masukan dari konsumen sehingga dapat melakukan perbaikan bila ada kekurangan terkait pelayanan yang diberikan.

Dengan memiliki relasi terhadap supplier yang bagus diharapkan kedepannya The Gangsa Ubud Private Villa \& Spa tidak kekurangan bahan baku makanan, dan bahan lain yang mampu menunjang operasional villa. 
Berdasarkan hasil kajian pada aspek keuangan untuk rencana pembangunan proyek The Gangsa Ubud Private Villa \& Spa diketahui bahwa jumlah kebutuhan dana (Initial Cash flow) untuk proyek pembangunan villa ini adalah sebesar Rp 49.021.583.000,-. Sumber dana diperoleh dari modal sendiri sebesar Rp 34.021.583.000,- dan pinjaman bank sebesar Rp 15.000.000,-. WACC sebesar 10,54\%, Payback Period yang diperoleh adalah 5,75 tahun, NPV yang diperoleh adalah positif sebesar Rp 11.707.906.000,-, IRR lebih besar nilainya daripada tingkat diskonto yaitu sebesar 14,85\%, PI diperoleh angka 1,24 dimana nilai tersebut lebih besar daripada 1, sedangkan AVR diperoleh angka 12,54\%.

Berdasarkan analisis Sensitivitas menunjukkan hasil bahwa Pada saat kondisi MODERAT menghasilkan NPV positif sebesar Rp 7.244.872.000 (layak) dengan IRR sebesar 13,55\% lebih besar dari biaya modal 10,77\% (layak). Payback period 5,97 tahun lebih cepat dari rencana proyek 10 tahun (layak) sedangkan PI 1,15 (layak). Secara keseluruhan investasi dikatakan layak karena tingkat pengembaliannya lebih besar dari biaya modal rata-rata tertimbang.

Pada saat kondisi PESIMIS menghasilkan NPV positif sebesar Rp 1.121.609.000 (layak) dengan IRR sebesar 11,47\% lebih besar dari biaya modal $11 \%$ (layak). Payback period 6,25 tahun lebih cepat dari rencana proyek 10 tahun (layak) sedangkan PI 1,02 (layak). Secara keseluruhan investasi dikatakan layak karena tingkat pengembaliannya lebih besar dari biaya modal rata-rata tertimbang.

Berdasarkan hasil penelitian dan kesimpulan yang telah diuraikan, maka saran yang dapat diberikan dengan penelitian ini sebagai bahan pertimbangan 
serta masukan yang berguna bagi pihak - pihak yang berkepentingan di masa yang akan datang yaitu Bagi manajemen The Gangsa Ubud Private Villa \& Spa hendaknya menggunakan standar kelayakan usaha untuk memastikan semua aspek telah diteliti dan hasil kelayakan menyatakan positif sehingga kelayakan dapat dilanjutkan. Hasil penelitian ini dilihat dari aspek pasar dan pemasaran, aspek keuangan maupun aspek lainnya telah menunjukkan hasil yang positif sehingga proyek pembangunan The Gangsa Ubud Private Villa \& Spa layak dilanjutkan.

Persaingan yang ketat memerlukan perbaikan dalam kualitas produk dan jasa. Rencana pembangunan sarana fisik yang baik dan sesuai dengan harapan tamu menjadi sangat penting untuk meningkatkan daya saing produk yang ditawarkan ditunjang dengan kualitas pelayanan (jasa) yang sempurna (excellent) akan mendukung usaha manajemen The Gangsa Ubud Private Villa \& Spa untuk dapat memenangkan persaingan.

\section{REFERENSI}

Brigham, E.F, Daves, P.R. 2008. Intermediate Financial Management. 10th Edition. South Western Cengage Learning

Husnan, S dan Muhamad. 2014. Studi Kelayakan Proyek. Edisi Keempat.Yogyakarta : UPP STIM YKPN

Husnan, S. 2008. Manajemen Keuangan: Teori dan Penerapan (Keputusan Jangka Panjang). Jilid 1 dan 2. Edisi Empat, Yogyakarta: BPFE

Darsono dan Ashari. 2005. Pedoman Praktis Memahami Laporan Keuangan. Jakarta. : Salemba Empat.

Fraser \& Ormiston, 2009. Understanding Financial Statements. 9th Edition. Prentice Hall.

Georgakellos, D. A. Marcis, A. M. 2009. Application of the semantic learning approach in the feasibility studies preparation training process. Information Systems Management. 
Internet: www.bps.go.id

Internet: $\underline{w w w . d a t a s t a t i s t i k-I n d o n e s i a . g o . i d}$

Internet : www.djppr.kemenkeu.go.id

Internet : www.id.wikipedia.org

Ismayanti.2010. Pengantar Pariwisata. Jakarta: PT Gramedia Widisarana.

Jones, C.P, 2004. Investment : Analysis and Management. Jakarta : Salemba Empat

Kasmir, dan Jakfar 2012. Studi Kelayakan Bisnis. Edisi Revisi. Jakarta, Kencana Prenada

Kotler, P. 2009. Manajemen Pemasaran. Edisi 13 Jilid 1. Jakarta: Penerbit Erlangga

PKF Consulting, 2006. Market Feasibility Study Proposed Hotel / Convention Center Facility Lancaster, Pennsylvania. (online),

Semarajaya, 2006. Analisis kelayakan privatisasi Rumah Sakit Sanglah di Denpasar, Tesis, Program Studi Magister Manajemen UNUD tidak dipublikasikan.

Sofyan, 2003. Studi Kelayakan Bisnis. Edisi Pertama. Yogyakarta: Graha Ilmu

Suratman, 2001. Studi Kelayakan Proyek - Teknik dan Prosedur Penyusuna Laporan, Edisi Pertama, Yogyakarta, J\&J Learning

Sutojo, S. 2006. Studi Kelayakan Proyek: Konsep, Teknik \& Kasus. Cetakan 5.Jakarta: Damar Mulia Pustaka

Syamsudin, 2002. Manajemen Keuangan Daerah. Jakarta: PT RajaGrafindo Persada

Umar, H. 2002. Metode Riset Bisnis. Jakarta : PT Gramedia Pustaka Utama

William, Gordon \& Jeffry. 2015. Investment. Singapore : Prentice Hall

Wijaya, B. 2009. Studi Kelayakan Investasi Penambahan Villa Pada PT Bagus AgroPelaga di Kabupaten Badung, Tesis, Program Studi Magister Manajemen UNUD tidak dipublikasikan. 